\title{
4-6 yaş çocuklarına etkinlik temelli STEM eğitiminin bilimsel süreç becerilerine etkisinin incelenmesi*
}

\author{
Investigate the effect of activity-based STEM education on scientific \\ process skills for 4-6 years old preschool \\ Muhammed Ünal ${ }^{1}$, Pelin Aksüt ${ }^{2}$
}

\author{
Makale Gecmisi \\ Geliş : 26 Temmuz 2020 \\ Düzeltme : 4 Subat 2021 \\ Kabul : 4 Mart 2021
}

\section{Makale Türü}

Araştrma Makalesi

\section{Article History}

Received : 26 July 2020

Revised : 4 February 2021

Accepted : 4 March 2021

Article Type

Research Article
Öz: Araştırmada, 4-6 yaş grubu çocuklarda etkinlik temelli STEM eğitiminin bilimsel süreç becerilerine etkisinin incelenmesi amaçlanmıştır. Çalışma grubu, benzeşik örnekleme yöntemi ile belirlenmiş olup; anaokulunda aynı yaş ve benzer gelişim dönemlerinde bulunan çocuklardan iki sınıf tespit edilerek bir sınıf deney (19 çocuk) diğer sınıf kontrol grubu (29 çocuk) olarak toplam 48 çocuk ile oluşturulmuştur. Veri toplama aracı olarak araştırmacının hazırladığı Kişisel Bilgi Formu ve Büyüktaşkapu'nun (2010) geliştirdiği Okul Öncesi Bilimsel Süreç Becerileri Ölçeği uygulanmıştır. Deney grubuna araştırmacı tarafından olusturulan Etkinlik Temelli STEM Eğitimi Uygulamaları, haftada üç gün olmak üzere, 8 hafta boyunca ( 24 etkinlik) ve her bir etkinlik için 45 dakika süre ayrılarak uygulanmıştır. Verilerin analizinde deney ve kontrol grupları arası ölçümlerde Mann Whitney U testi, öntest-sontest puan karşılaştırmaları için Wilcoxon İşaret Sıraları testi yapılmıştır. Analiz sonuçlarına göre Etkinlik Temelli STEM Eğitimi Uygulamalarının çocukların bilimsel süreç becerilerini olumlu düzeyde etkilediği görülmüștür.

Anahtar Kelimeler: Okul Öncesi Dönem, Bilimsel Süreç Becerileri, Etkinlik Temelli STEM Eğitimi Uygulamaları, STEM.

Abstract: In the study, it was aimed to examine the effect of activity-based STEM education on scientific process skills in children aged 4-6 years. The study group is determined by homogeneous sampling,method; Two classes were determined from the children at the same age and similar developmental stages in kindergarten, and a class experiment (19 children) and the other class control group ( 29 children) were formed with a total of 48 children. The Personal Information Form prepared by the researcher and the Preschool Scientific Process Skills Scale developed by Büyüktaşkapu (2010) were applied as data collection tools. Activity Based STEM Training Practices, created by the researcher, were applied to the experimental group for three weeks a week for 8 weeks (24 activities) and 45 minutes for each activity. In the analysis of the data, Mann Whitney $U$ test was used for measurements between experimental and control groups, and Wilcoxon Signed- rank test was used for pretest-posttest score comparisons. According to the results of the analysis, it was seen that Activity Based STEM Education Applications positively affect the scientific process skills of children.

Keywords: Preschool Period, Scientific Process Skills, Activity-Based STEM Training Practices, STEM. 


\section{SUMMARY}

\section{Introduction}

Children are curious about the world around them while they play, they observe and they like to think about the world (Eshach and Fried, 2005; Ramey-Gassert, 1997). From the moment children start to make sense of their environment, they begin to use basic scientific process skills and learn science (Şahin, Yıldırım, Sürmeli and Güven, 2018). The preschool period is an important period in acquiring and developing basic scientific process skills (French, 2004). Therefore, techniques, methods, and approaches for acquiring scientific process skills in preschool education environments are important for science teaching (Şahin et al., 2018).

This research, interdisciplinary and integrated implementation of STEM education, use of rich content and effective materials in the applied activities, 21st-century skills, collaborating, creative and innovative, high communication skills, curious and interested, learning to learn, science literate individuals. It is important to support the scientific process skills that the child will encounter in daily life. In light of these, this research; It is aimed to examine the effects of activity-based STEM education applications on 4-6 years old children on scientific process skills.

\section{Method}

The pattern of this research is paired pattern from semi-experimental patterns (Büyüköztürk, Çakmak, Akgün, Karadeniz and Demirel, 2012; Creswell, 2013). In this pattern, two of the ready-made groups are tried to be matched over certain variables. Paired groups are randomly assigned to transaction groups, but matching does not guarantee that the groups included in the study are equivalent. Although this is a serious limitation, it is stated as an important alternative pattern in cases where random selection cannot be made. In this research, pretest-posttest matched control group pattern was used (Büyüköztürk et al., 2012). This pattern is the design in which the participants in the experimental and control groups measured the dependent variable with pretest-posttest applications (Johnson and Christensen, 2014). Pre and post-test measurements were made to both experimental and control groups.

\section{Results}

As a result of the analyzes, children who participated in Activity Based STEM Education Practices and children who did not participate in such practice; There is a statistically significant difference between the observation subscale posttest scores: $U=0.00, p<0.05$. $(z=-5.917 ; p=0.00 ; p<0.05)$. Considering the mean ranks regarding the observation sub-skill, it was determined that it was in favor of the children participating in the Activity Based STEM Training Practices. There is a statistically significant difference between the classification subscale posttest scores: $U=4.00, p<0.05$. $(z=-5.843 ; p=0.00 ; p<0.05)$. Considering the average ranks regarding the classification sub-skill, it was determined that it was in favor of the children participating in Activity Based STEM Education Practices. There is a statistically significant difference between the Prediction subscale posttest scores: $U=0.00, p<0.05$. $(z=-5.887 ; p=0.00 ; p$ $<0.05)$. Considering the average ranks regarding the Prediction sub-skill, it was determined that it was in favor of the children participating in the Activity Based STEM Training Practices. There is a statistically 
significant difference between the measurement subscale posttest scores: $\mathrm{U}=0.00, \mathrm{p}<0.05$. $(\mathrm{z}=-6.262 ; \mathrm{p}$ $=0.00 ; \mathrm{p}<0.05)$. Considering the mean ranks of the measurement sub-skill, it was determined that it was in favor of the children participating in the Activity Based STEM Training Practices. There is a statistically significant difference between the Post Data Scale subscale posttest scores: $U=0.00, p<0.05$. ( $z=-5.894$; $\mathrm{p}=0.00 ; \mathrm{p}<0.05)$. Considering the rank averages regarding the Sub-skill of Saving Data, it is determined that it is in favor of the children participating in the Activity Based STEM Training Practices. Conclusion There is a statistically significant difference between the sub-test post-test scores: $U=7.00, p<0.05$. $(z=$ $5,807 ; \mathrm{p}=0.00 ; \mathrm{p}<0.05)$. Considering the rank averages regarding the sub-skill subtraction, it is determined that it is in favor of the children participating in the Activity Based STEM Training Practices.

\section{Conclusion and Discussion}

Activity Based STEM Education Applications have contributed positively to the scientific process skills of children, this result may be thought to be the Activity Based STEM Education Applications. Considering the literature, the effects of various education and training programs on scientific process skills are supported (Balbay, 2018; Günşen, Fazlığlu and Bayır, 2017; Öcal, 2018) by using STEM education applications in preschool period (Alabay, 2013; Alabay and Özdoğan, 2018; Büyüktaşkapu, 2010; Civelek and Akamca, 2018; Karataş, 2018; Kıldan and Pektaş, 2009; Özkan, 2015; Sağırekmekçi, 2016; Tekerci and Kandır, 2017; Toprakkaya, 2016; Şahin, Güven and Yurdatapan, 2011; Yağc1, 2016), such as Activity-Based STEM Education supports the findings regarding the meaningful difference in children's scientific process skills. When the studies conducted in this context are analyzed, the findings that the scientific process skills of children can develop are supported by appropriate activity practices to be given regarding scientific process skills.

There is a significant difference in the scientific process skills of 55-72 month-old children (N: 27) based on inquiry-based science activities (Alabay and Özdoğan, 2018), the STEM program (ESTEMEP) developed for 60-66 month-old children (N:26) who continue preschool education favorably supports the scientific process skills of children (Öcal, 2018), the science teaching program based on the constructivist approach (YYD-BÖP) is effective on the scientific process skills of 5-year-old children (N: 40) (Günşen, Fazlıoğlu and Bayır, 2017), Brain-Based Learning Science Program of 60-72 months old children (N: 265) is effective in providing children with scientific process skills (Özkan, 2015), there is a significant difference in the skills of preschool children (N: 13) to use scientific processes at the end of project-based educational practices (Şahin et al., 2011), science teaching program based on constructivist approach improves the scientific process skills of preschool children (N: 80) (Büyüktaşkapu, 2010), in studies showing that Drama-Based Early STEM Program in Education (N: 40) positively affects the scientific process and creative thinking skills (Çilengir-Gültekin, 2019), the data obtained in this research will increase the scientific process solving skills of children with Activity Based STEM Education Practices. It appears to support the finding. 


\section{GİRİŞ}

Çocuklar oyun oynarlarken çevrelerindeki dünyayı merak ederler, gözlemlerler ve dünya hakkında düşünmekten hoşlanırlar (Eshach ve Fried, 2005; Ramey-Gassert, 1997). Bu dönemde çocuklar bir bilim insanı gibi araştırmak, keşfetmek, yeni şeyler yaratmak ve öğrenmek için oldukça meraklıdırlar (Holt, 1991). Keşfedip, araştırırken içgüdüsel olarak birçok soru sorarlar - "neden, nasıl, nerede ve ne zaman vb. ?” (Trundle ve Saçkes, 2015). Aslında çocuklar çevresini anlamlandırmaya başladıkları andan itibaren temel bilimsel süreç becerilerini kullanmaya ve fen öğrenmeye başlarlar (Şahin, Yıldırım, Sürmeli ve Güven, 2018). Okul öncesi dönemin temel bilimsel süreç becerilerin kazandırılmasında ve geliştirilmesinde önemli etkiye sahip olduğu düşünüldüğünde (French, 2004) eğitim ortamlarında bilimsel süreç becerilerinin kazandırılmasına ilişkin teknik, yöntem ve yaklaşımlar fen öğretimi için önem taşımaktadır (Şahin, Yıldırım, Sürmeli ve Güven, 2018). Öyle ki Öncesi Eğitimi Programına göre (MEB, 2013) göre, çocuklar tecrübe ve çevre farkındalığ1 kazanırken, onların bilimsel süreç becerilerini kullanmalarına özen gösterilmelidir. Bunun yanında, bilimsel süreç becerilerini Amerikan Fen Eğitimi Geliştirme Derneği (American Association for the Advancement of Science [A.A.A.S.], 1993) büyük ölçüde aktarılabilir, çeşitli fen disiplini için özümsenmiş, bilim insanlarının doğru tutumlarının yansımaları olarak kabul gören beceri grubu olarak ifade edilmiştir.

Bilimsel süreç becerileri desteklenen çocukların kazandıkları yaratıcılık ve eleştirel düşünme 21 . yüzyıl modern toplumunun ihtiyaç duyduğu üreten, bilimsel düşünen, araştırmacı insan özelikleri arasındadır (Civelek ve Akamca, 2018; Koray, Köksal, Özdemir ve Presley, 2007; Yağc1, 2016). Çocukların okul öncesi dönemde bilimsel süreç becerilerinin desteklenmesi, tek boyutlu görülmemeli ayrıca salt bilgiyi kazanmaktan çok bilimin nasıl yapılacağını uygulamalı olarak kazandırmak amaçlanmalıdır (Andersson ve Gullberg, 2012; Ayvacı, 2010; Bartan ve Başal, 2018; Brenneman, 2011; Çeliköz ve Erişen, 2013; Güler ve Akman, 2006; Harlen, 1989; Trundle ve Saçkes, 2015). Kandemir (2011) bilgi ve teknoloji çağında bilimsel süreç becerilerinin öneminin arttı̆̆ını, çocuklara erken yaşlarda bu becerilerinin öğretilmesi zorunlu hale geldiğini belirtmiştir. 21 . yüzyll becerilerine sahip bireylerin temel bilimlerden 1şığında teknoloji ve mühendisliği entegre ederek yenilikler yapması gerekliliğinden hareketle STEM eğitimi önemli rol oynadığı ifade edilmektedir (Uğraş, 2017; Uyanık-Balat ve Günşen, 2017).

STEM ifadesi 1990'lı yıllarda Amerika Ulusal Bilim Vakfi (NSF) tarafindan (Bybee, 2010); Fen (Science), Teknoloji (Technology), Mühendislik (Engineering) ve Matematik (Mathematics) kelimelerinin baş harflerinin bir araya getirilmesiyle oluşmuştur. Bu bağlamda, STEM eğitim yaklaşımı; teknoloji üretme ve geliştirme gücünü, ülke ekonomisinin gelişmesini, yeni iş firsatları 
yaratmayı, küresel bilgi çağına ulaşmış nesiller yetiştirmeyi hedeflemektedir (Çorlu, Capraro ve Capraro, 2014; Honey, Pearson ve Schweingruber, 2014; Yildırım ve Altun, 2015). STEM yaklaşımına uygun etkinlikler ile çocukların bilimsel araştırma ve sorgulama yapma, tasarım uygulamalarıyla tasarım yapma, deneyi planlama, farklı değişkenleri tespit etme becerilerini kullanması amaçlanmaktadır (Yamak, Bulut ve Dündar, 2014). Ayrıca uygulamalı etkinliklerle verilen STEM eğitiminin önemli boyutlarından biri olan, bilimsel süreç becerilerinin geliştirilmesidir (Strong, 2013).

21. Yüzyll Öğrenme Ortaklığ1 (The Partnership for 21st Century Learning [P21], 2017) çerçevesinde 21. yüzyıl becerilerinden yenilik ve yaratıcılık, iletişimsel beceriler, bilgi okur-yazarlığ1, verimlilik gibi bilimsel süreç becerilerine destek sağlayan ve STEM eğitimine ilişkin kazanımlar okul öncesi dönemde çocuklara verilmelidir. Okul öncesi dönemde STEM eğitimine ilişkin yapılan çalışmaların (Akçay, 2019; Alan, 2020; Atik, 2019; Aydın, 2019; Bal, 2018; Deniz-Özgök, 2019; Güldemir, 2019; Haden, Jant, Hoffman, Marcus, Geddes ve Gaskins, 2014; Ing, 2014; Jamil, Linder ve Stegelin, 2018; Kavak, 2020; Kazakoff, Sullivan ve Bers, 2013; Lamb, Akmal, Petrie, 2015; Lippard, Lamm, Tank ve Choi, 2019; Öcal, 2018; Park, Park ve Bates, 2018; Tippett ve Milford, 2017; Uğraş, 2017; Üret, 2019; Vurucu, 2019) son y1llarda gerçekleştirilmiş olması dikkat çekmektedir. Ayrıca, uygun etkinliklerle çocukların okul öncesi dönemde bilimsel süreç becerilerinin kullanma yeterliliğinin geliştirilebileceği (Ayvacı, 2010) belirtilirken yapılan araştırmalara bakıldığında; okul öncesi dönemdeki çocukların bilimsel süreçleri kullanma düzeylerini proje tabanlı eğitim uygulamaları ile geliştirilebileceği (Şahin, Güven ve Yurdatapan, 2011), dış alan sorgulama tabanlı bilim etkinliklerinin bilimsel süreç becerileri üzerine etkili olduğu (Alabay ve Özdoğan, 2018); Sciencestart destekli fen eğitim programının 60-72 Aylık çocukların bilimsel süreç becerilerine etkisi olduğu (Alabay, 2013); uygulanan çocuklara uygulanan bilim eğitimi programının bilimsel süreç becerilerine etkisinin olduğu (Büyüktaşkapu, Çeliköz ve Akman, 2012); uygulanan beyin temelli öğrenmeye dayanan fen eğitimi programının çocukların bilimsel süreç becerileri üzerinde etkili olduğu (Özkan, 2015) görülmektektedir. Ayrıca okul öncesi öğretmenlerinin temel bilimsel süreç becerilerini kullanma düzeylerinin düşük düzeyde olduğu (Kefi, Çeliköz ve Erişen, 2013) görülmektedir. Bu araştırma, STEM eğitiminin disiplinler arası ve bütünleşik uygulanması, uygulanan etkinliklerde zengin içerikli ve uygun materyaller kullanılması, 21.yy becerilerine sahip, işbirliği yapan, yaratıcı ve yenilikçi olan, iletişim becerileri yüksek, merak eden ve ilgi duyan, öğrenmeyi öğrenen, bilim okuryazarı bireyler olarak yetişmelerine olanak sağlanmas1, çocuğun günlük hayatta karşılaşacağı bilimsel süreç becerilerinin desteklenmesi açısından önem taşımaktadır. Bu bağlamda bu araştırmada; 4-6 yaş çocuklarının etkinlik temelli STEM eğitimi uygulamalarının bilimsel süreç becerilerine olan etkiyi incelemeyi amaçlamıştır. 


\section{YÖNTEM}

\section{Araştırma Modeli}

$\mathrm{Bu}$ araştırmanın modelini yarı deneysel desenlerden eşleştirilmemiş/eşdeğer olmayan karşılaştırma grup deseni oluşturmaktadır (Christensen, Johnson ve Turner, 2011). Bu desende, deney ve kontrol grupları oluşturulur. Bu gruplar yansız atama şeklinde oluşturulmamıştır. Gruplar bağımlı değişken puanlarına yönelik benzer özellikler gösterse de ölçülebilen veya ölçülemeyen birçok değişken durum söz konusudur ve bu değişkenler grupları farklılaştırabilir (Tuncer, 2020). Her iki grup (deney ve kontrol) oluşturulurken; velilerin izinleri, aile katılımı, okul kabulü ve diğer deneysel çalışmalar dikkate alınmıştır.

\section{Çalışma Grubu}

Araştırmanın çalışma grubunu 2018-2019 eğitim ve öğretim yılı bahar döneminde Bolu ili Merkez ilçesinde bağımsız bir anaokuluna devam eden çocuklar oluşturmaktadır. 4-6 yaş arası toplam 48 çocuktan, deney grubunda 19 çocuk, kontrol grubunda 29 çocuk yer almaktadır.

Çalışma grubu oluşturulurken amaçlı örnekleme yöntemlerinden benzeşik örnekleme ile bağımsız anaokulu belirlenmiştir. Benzeşik örnekleme, araştırma problemiyle ilgili evrende yer alan benzeşik bir alt grubundan ya da durumundan oluşmasıdır (Büyüköztürk ve diğerleri, 2012). Bu çerçevede çalışma grubunun oluşmasında anaokulunda 4-6 yaş grubundaki 2 sınıf belirlenmiş olup seçkisiz atama ile biri deney grubu biri kontrol grubu belirlenmiştir. Araştırmaya katılan çocukların demografik özelliklerine ilişkin verilerin dağglımı Tablo 1'de yer almaktadır.

Tablo 1. Araştırmaya katılan çocukların demografik bilgilerin dağılımı

\begin{tabular}{llcccccc}
\hline & & \multicolumn{2}{c}{ Deney Grubu } & \multicolumn{2}{c}{ Kontrol Grubu } & \multicolumn{2}{c}{ Toplam } \\
\cline { 3 - 7 } & & $\mathbf{N}$ & $\mathbf{0}$ & $\mathbf{N}$ & $\mathbf{0}$ & $\mathbf{N}$ & $\mathbf{\%}$ \\
\hline \multirow{3}{*}{ Cinsiyet } & K1z & 11 & 57,9 & 11 & 37,9 & 22 & 45,8 \\
& Erkek & 8 & 42,1 & 18 & 62,1 & 26 & 54,2 \\
& Toplam & 19 & 100 & 29 & 100 & 48 & 100 \\
Çocukyyyyyyyyyyy & 4-5 Yaş & 9 & 47,4 & 9 & 31 & 18 & 37,5 \\
& 5-6 Yaş & 10 & 52,6 & 20 & 69 & 30 & 62,5 \\
& Toplam & 19 & 100 & 29 & 100 & 48 & 100 \\
\hline
\end{tabular}

\section{Veri Toplama Araçları}

$\mathrm{Bu}$ araştırmada, katılımcılara ait demografik bilgilerin toplanmasında araştırmacı tarafindan oluşturulan "Kişisel Bilgi Formu" ve çocukların bilimsel süreç becerilerini belirlemek amactyla Büyüktaşkapu (2010) tarafindan geliştirilen “Okul Öncesi Bilimsel Süreç Becerileri Ölçeği” kullanılmıştır. 


\section{Okul Öncesi Bilimsel Süreç Becerileti Ölçeği}

Büyüktaşkapu (2010) tarafından geliştirilen Okul Öncesi Bilimsel Süreç Becerileri Ölçeği, anaokuluna devam eden 60-72 aylık çocukların bilimsel süreç becerilerinin belirlenmesi amacıyla geliştirilmiştir. Okul Öncesi Bilimsel Süreç Becerileri Ölçeğinde; gözlem yapma, sınıflama, ölçme, tahmin etme, verileri kaydetme ve sonuç çıkarma olmak üzere 6 temel süreç becerisi yer almaktadır. Ölçeğin bilimsel süreç becerilerine (altı faktör) yönelik toplam varyans açıklama oranı \%65'tir. Ölçeğin güvenirliğine ilişkin yapılan ölçümlerde Cronbach Alpha ve testi yarılama yöntemi sonucunda güvenirlik katsayısı .81', testi yarılama güvenirlik katsayısı ise .79 olarak tespit edilmiştir.

Ölçekte her bir temel bilimsel süreç becerisi için etkinliklerde 0,1 ve 2 puanları alınmaktadır. Örneğin sınıflama becerisini ölçerken çocuklardan, midye kabuklarını bir özelliğine göre (Örn; boyut) sınıflaması istenir. Başka bir özelliğe göre tekrar (Örn; rengi) sınıflaması istenir ve çocuk sinıflama yapamazsa 0; bir sinıflama yaparsa 1; daha fazla sinıflama yaparsa 2 puan almaktadır. Diğer her bir beceri grupları için de aynı süreç işlemektedir. Çocuğun ölçekten alacağ1 en düşük 0; en yüksek 48 puandır (Büyüktaşkapu, 2010). Ölçeğin uygulanmasına yönelik araştırmacı eğitim almamış, çocuklara araştırmacı tarafından bireysel olarak uygulanmıştır. Ölçeğin uygulanmasına ilişkin ebeveynlerden gerekli izinler alınmıştır.

\section{İslem Süreci}

Temel bilimsel süreç becerileri doğrultusunda Etkinlik Temelli STEM Eğitimi Uygulamaları kapsamında, araştırmacı tarafından 24 adet bütünleştirilmiş etkinlik hazırlanmıştır. Hazırlanan etkinlikler çocukların gelişim ve yaş özelliklerine, bilimsel süreç becerilerine uygun kazanım ve göstergelere, bu becerileri desteklemeye yönelik çocukların günlük yaşamsal deneyimlerinde öğrenme firsatları sunulması amaçlanarak hazırlanmıştır. Etkinlik Temelli STEM Eğitimi Uygulamaları hazırlama sürecinde, 2013 yllında güncellenen Milli Eğitim Bakanllğı Okul Öncesi Eğitimi Programı'nda (36-72 Aylık) bulunan uygun kazanım ve göstergeler doğrultusunda etkinlikler hazırlanmıştır. Araştırmacı tarafından hazırlanan etkinlikler, etkinliklerin temel bilimsel süreç becerilerini ne kadar kapsadığ1, etkinliklerin bilimsel süreç becerileri alt bölümlerine göre bilimsel süreç becerileri için hedeflenen tüm kazanımları içerme durumları, etkinliklerin hedeflenen yaş grubuna uygunluğu, etkinliklerin çocukların ilgisini çekecek düzeyde olması, etkinliklere ayrılacak sürenin yeterliliği, kullanılacak materyallerin uygunluğu, etkinliklerin STEM alanlarına uygunluğu açısından incelenmek üzere uzman görüşüne sunulmuştur. Bu bağlamda, fen eğitimi alanında iki alan uzmanı, bilişim teknolojileri alanında bir alan uzmanı ve matematik alanında bir alan uzmanından görüşleri alınmıştır. Uzman görüşlerinin uygunluk derecesi, Miles ve Huberman'a 
(1994) göre görüşlerin benzerlik uygunluğu alınarak oluşturduğu güvenirlik formülü ile (Güvenirlik = Görüş Birliği/ (Görüş Birliği + Görüş Ayrllığı)) 0,96 şeklinde hesaplanmıştır.

Tablo 2. Etkinlik temelli STEM eğitimi uygulamalarının etkinlikleri, temel bilimsel süreç becerileri ve etkinlikteki STEM entegrasyonu

\begin{tabular}{|c|c|c|c|c|c|c|c|c|c|c|}
\hline \multirow[b]{2}{*}{ Etkinlikler } & \multicolumn{6}{|c|}{ Temel Bilimsel Süreç Becerileri } & \multicolumn{4}{|c|}{ Etkinlikteki STEM Entegrasyonu } \\
\hline & Gözlem & Sinıflandırma & $\begin{array}{l}\text { Tahmin } \\
\text { Etme }\end{array}$ & Ölçme & $\begin{array}{c}\text { Verileri } \\
\text { Kaydet } \\
\text { me }\end{array}$ & Çikarım & Fen & Teknoloji & Mühendislik & Matematik \\
\hline $\begin{array}{l}1 \text { Bir Tohum } \\
\text { Ekelim }\end{array}$ & $\mathrm{X}$ & $\mathrm{X}$ & & & & & & $\mathrm{X}$ & & \\
\hline $\begin{array}{l}\text { 2. Doğal } \\
\text { Fırçalar } \\
\text { Yapiyorum }\end{array}$ & $\mathrm{X}$ & & & & & & $\mathrm{X}$ & $\mathrm{X}$ & $\mathrm{X}$ & \\
\hline $\begin{array}{l}\text { 3. Mancinıkla } \\
\text { Basketbol } \\
\text { Oynayalım }\end{array}$ & $\mathrm{X}$ & & & $\mathrm{X}$ & & & & $\mathrm{X}$ & $\mathrm{X}$ & \\
\hline $\begin{array}{l}\text { 4. Mutlu } \\
\text { Haritalar }\end{array}$ & & & & & $\mathrm{X}$ & & & $\mathrm{X}$ & & $\mathrm{X}$ \\
\hline $\begin{array}{l}\text { 5. Geri } \\
\text { Dönüsstürüyo } \\
\text { rum } \\
6 .\end{array}$ & $\mathrm{X}$ & & & & & & & $\mathrm{X}$ & $\mathrm{X}$ & \\
\hline $\begin{array}{c}\text { Saksılarımızı } \\
\text { Yapiyoruz } \\
7 .\end{array}$ & $\mathrm{X}$ & & & & & $\mathrm{X}$ & $\mathrm{X}$ & & $\mathrm{X}$ & \\
\hline $\begin{array}{l}\text { Marshmallow } \\
\text { Kulelerimiz } \\
\text { 8. Legolar1 }\end{array}$ & $\mathrm{X}$ & & & $\mathrm{X}$ & & & $\mathrm{X}$ & $\mathrm{X}$ & $\mathrm{X}$ & $\mathrm{X}$ \\
\hline $\begin{array}{l}\text { Sepete } \\
\text { Koyalım } \\
\text { 9. Köprü Ne}\end{array}$ & & $\mathrm{X}$ & & & & & & & $\mathrm{X}$ & $\mathrm{X}$ \\
\hline $\begin{array}{l}\text { Kadar } \\
\text { Sağlam? }\end{array}$ & $\mathrm{X}$ & & & $\mathrm{X}$ & & & $\mathrm{X}$ & $\mathrm{X}$ & $\mathrm{X}$ & $\mathrm{X}$ \\
\hline $\begin{array}{l}\text { 10. Mümü’yü } \\
\text { Kurtaralım }\end{array}$ & & & $\mathrm{x}$ & $\mathrm{X}$ & & & $\mathrm{X}$ & & $\mathrm{X}$ & \\
\hline $\begin{array}{l}\text { 11. Bardak } \\
\text { Kule } \\
\text { 12. Attk }\end{array}$ & & & $\mathrm{X}$ & $\mathrm{X}$ & & & & & $\mathrm{X}$ & $\mathrm{x}$ \\
\hline $\begin{array}{l}\text { Materyalden } \\
\text { Halı } \\
\text { Yapiyorum } \\
\text { 13. Havdi En }\end{array}$ & $\mathrm{X}$ & $\mathrm{X}$ & & & & & $\mathrm{X}$ & & $\mathrm{x}$ & \\
\hline & & & $\mathrm{X}$ & $\mathrm{X}$ & & $\mathrm{x}$ & $\mathrm{X}$ & & $\mathrm{X}$ & $\mathrm{X}$ \\
\hline $\begin{array}{l}\text { 14. Müzik } \\
\text { Aletleri } \\
\text { Yarışıor }\end{array}$ & & $\mathrm{X}$ & $\mathrm{X}$ & & $\mathrm{X}$ & & & & $\mathrm{X}$ & \\
\hline $\begin{array}{c}\text { 15. Yelkenli } \\
\text { Yüzdürüyoru } \\
\text { m }\end{array}$ & & $\mathrm{X}$ & & $\mathrm{X}$ & & $\mathrm{X}$ & $\mathrm{X}$ & $\mathrm{X}$ & $\mathrm{X}$ & \\
\hline & & ken Çocukluk & $\begin{array}{l}\text { alssmaları } \\
\text { t5. Sayı } 1\end{array}$ & $\begin{array}{l}\text { ergisi } \\
\text { Nisan }\end{array}$ & $\begin{array}{ll}\text { D21 } & \text { Jour } \\
& \text { Vol }\end{array}$ & $\begin{array}{l}\text { al of Early } \\
\text { ne 5. Issue }\end{array}$ & $\begin{array}{l}\text { Childh } \\
1 \cdot \text { Apr }\end{array}$ & d Studies & & \\
\hline
\end{tabular}




$\begin{array}{llllll}\begin{array}{l}\text { 16. Ayşe } \\ \text { Bisiklet }\end{array} & & & & & \\ \text { Sürüyor } \\ \text { 17. }\end{array}$

Ön test uygulamasının ardından deney grubundaki çocuklara; etkinlikler ortalama 40-45 dakika sürmekle beraber toplamda 8 hafta olmak üzere, haftada 3 gün (Pazartesi, Çarşamba, Cuma) olarak araştırmacı tarafından uygulanmıştır. Çocukların rahat hissederek etkinliklere aktif katılımının daha üst düzeyde olacağı düşünülerek kendi sınıflarında uygulamalar yürütülmüştür. Öyle ki etkinlik uygulamalarında çocuklar aktif rol almışlardır. Etkinliklerde çocuklar için tehlikeli olabilecek materyallerin kullanılmamasına özellikle dikkat edilmiştir. Etkinlikler plana uygun büyük grup ve küçük gruplarla yapılmıştır. Deney grubundaki Etkinlik Temelli STEM Eğitimi Uygulamaları tamamlandıktan sonra deney ve kontrol gruplarına ön testlerin uygulandığı aynı ortamda ve şartlarda son test Okul Öncesi Bilimsel Süreç Becerileri Ölçeği uygulanmıştır.

\section{Verilerin Analizi}

4-6 yaş Okul Öncesi Bilimsel Süreç Becerileri Ölçeği ile toplanan verilerin analizinde; frekans, yüzde, aritmetik ortalama gibi betimsel istatistikler ile araştırma sorusunu test etmeye yönelik parametrik olmayan istatistiksel testler kullanılmıştır. Verilerin dağılımı araştırmacılar tarafından yaygın olarak kullanılan Kolmogorov-Smirnov ve Shapiro-Wilk Testleri kullanılarak incelenmiştir. 
Normal dağılım göstermediği ve 30'dan az sayıda verilerin analizinde uygun parametrik olmayan testler kullanılmıştır. Deney ve kontrol gruplarının uygulama öncesindeki denkliğinin incelenmesi amacıyla ön test puanları, Mann Whitney U testi ile analiz edilmiştir. Gruplara ilişkin uygulama öncesi ve sonrası puanların farklılığına yönelik ön test-son test puanları Wilcoxon İşaret Sıraları testi ile analiz edilmiştir. Son olarak da deney ve kontrol grubu çocuklarının uygulama sonu son test puanlarının karşılaştırılmasında Mann Whitney U testi kullanılmıştır.

\section{BULGULAR}

Anaokuluna devam eden 4-6 yaş çocukları için hazırlanan Etkinlik Temelli STEM Eğitimi Uygulamalarının uygulama sürecine geçilmeden önce deney ve kontrol gruplarının Okul Öncesi Bilimsel Süreç Becerileri Ölçeğinden aldıkları ön test puanlarına ilişkin betimsel istatistikleri Tablo 3 de verilmiştir.

Tablo 3. Deney ve kontrol gruplarının okul öncesi bilimsel süreç becerileri ölçeği alt boyutları ön test puanlarına ilişkin betimsel istatistikleri

\begin{tabular}{|c|c|c|c|c|}
\hline \multicolumn{2}{|c|}{ Ön Test } & \multirow{2}{*}{$\frac{\mathbf{N}}{19}$} & \multirow{2}{*}{$\frac{\mathbf{X}}{2,89}$} & \multirow{2}{*}{$\frac{\text { SS }}{0,875}$} \\
\hline G̈̈lem & Deney Grubu & & & \\
\hline Gozlem & Kontrol Grubu & 29 & 3,28 & 1,099 \\
\hline \multirow{2}{*}{ Siniflama } & Deney Grubu & 19 & 1,11 & 1,761 \\
\hline & Kontrol Grubu & 29 & 1,52 & 1,805 \\
\hline \multirow{2}{*}{ Tahmin Etme } & Deney Grubu & 19 & 2,05 & 0,848 \\
\hline & Kontrol Grubu & 29 & 2,79 & 0,902 \\
\hline \multirow{2}{*}{ Ölçme } & Deney Grubu & 19 & 1,42 & 0,769 \\
\hline & Kontrol Grubu & 29 & 2,45 & 1,121 \\
\hline \multirow{2}{*}{ Verileri Kaydetme } & Deney Grubu & 19 & 1,79 & 0,855 \\
\hline & Kontrol Grubu & 29 & 2,31 & 1,257 \\
\hline \multirow{2}{*}{ Sonuç Çıkarma } & Deney Grubu & 19 & 2,11 & 1,243 \\
\hline & Kontrol Grubu & 29 & 2,76 & 1,354 \\
\hline
\end{tabular}

Tablo 3’e göre Gözlem alt boyutu ön test puanlarının aritmetik ortalamalarına bakıldığında, deney grubundaki çocukların puan ortalamalarının 2.89 iken, kontrol grubundaki çocukların puan ortalamalarının ise 3.28 olduğu saptanmıștır. Sınıflama alt boyutu ön test puanlarının aritmetik ortalamalarına bakıldığında, deney grubundaki çocukların puan ortalamalarının 1,11 iken, kontrol grubundaki çocukların puan ortalamalarının 1,52 olduğu; tahmin etme alt boyutu ön test puanlarının aritmetik ortalamalarına bakıldığında, deney grubundaki çocukların puan ortalamalarının 2,05 iken, kontrol grubundaki çocukların puan ortalamalarının ise 2,79 olduğu; ölçme alt boyutu ön test puanlarının aritmetik ortalamalarına bakıldığında, deney grubundaki çocukların puan ortalamalarının 1,42 iken, kontrol grubundaki çocukların puan ortalamalarının ise 2,45 olduğu; verileri kaydetme alt boyutu ön test puanlarının aritmetik ortalamalarına bakıldığında, deney grubundaki çocukların puan ortalamalarının 1,79 iken, kontrol grubundaki çocukların puan ortalamalarının ise 2,31 olduğu; sonuç Çıkarma alt boyutu ön test puanlarının aritmetik 
ortalamalarına bakıldığında, deney grubundaki çocukların puan ortalamalarının 2,11 iken, kontrol grubundaki çocukların puan ortalamalarının ise 2,76 olduğu saptanmıştır.

4-6 yaş çocukların okul öncesi bilimsel süreç becerileri ölçeği son test puanlarına ilişkin betimsel istatistik sonuçları Tablo 3’te verilmiştir.

Tablo 4. Deney ve kontrol gruplarının okul öncesi bilimsel süreç becerileri ölçeği son test puanlarına ilişkin betimsel istatistikleri

\begin{tabular}{lcccc}
\hline & Son Test & N & X & SS \\
\hline \multirow{2}{*}{ Gözlem } & Deney Grubu & 19 & 7,26 & 0,872 \\
& Kontrol Grubu & 29 & 2,86 & 0,789 \\
Sinıflama & Deney Grubu & 19 & 6,74 & 1,240 \\
\multirow{2}{*}{ Tahmin Etme } & Kontrol Grubu & 29 & 1,86 & 1,125 \\
\multirow{2}{*}{ Ölçme } & Deney Grubu & 19 & 5,58 & 0,902 \\
& Kontrol Grubu & 29 & 1,69 & 1,168 \\
\multirow{2}{*}{ Verileri Kaydetme } & Deney Grubu & 19 & 5,58 & 1,071 \\
\multirow{2}{*}{ Sonuç Çıkarma } & Kontrol Grubu & 29 & 1,93 & 0,530 \\
& Deney Grubu & 19 & 6,89 & 0,875 \\
& & 29 & 2,41 & 0,946 \\
& Kontrol Grubu & 19 & 6,63 & 1,342 \\
& Deney Grubu & 29 & 2,03 & 1,375 \\
\hline
\end{tabular}

Tablo 4'e göre; Gözlem alt ölçeği son test puanlarının aritmetik ortalamalarına bakıldığında, deney grubundaki çocukların puan ortalamaları 7,26 iken, kontrol grubundaki çocukların puan ortalamaları 2,86 olduğu saptanmıştır. Sınıflama alt ölçeği son test puanlarının aritmetik ortalamalarına bakıldığında, deney grubundaki çocukların puan ortalamaları 6,74 iken, kontrol grubundaki çocukların puan ortalamaları 1,86 olduğu; tahmin Etme alt ölçeği son test puanlarının aritmetik ortalamalarına bakıldığında, deney grubundaki çocukların puan ortalamaları 5,58 iken, kontrol grubundaki çocukların puan ortalamaları 1,69 olduğu; ölçme alt ölçeği son test puanlarının aritmetik ortalamalarına bakıldığında, deney grubundaki çocukların puan ortalamaları 5,58 iken, kontrol grubundaki çocukların puan ortalamaları 1,93 olduğu; verileri kaydetme alt ölçeği son test puanlarının aritmetik ortalamalarına bakıldığında, deney grubundaki çocukların puan ortalamaları 6,89 iken, kontrol grubundaki çocukların puan ortalamaları 2,41 olduğu; sonuç Çıkarma alt ölçeği son test puanlarının aritmetik ortalamalarına bakıldığında, deney grubundaki çocukların puan ortalamaları 6,63 iken, kontrol grubundaki çocukların puan ortalamalar1 2,03 olduğu gözlenmiştir.

4-6 yaş okul öncesi çocukları için hazırlanan Etkinlik Temelli STEM Eğitimi Uygulamaları sürecine başlamadan önce deney ve kontrol gruplarının Bilimsel Süreç Becerileri Ölçeğinden aldıkları ön test puanları arasında anlamlı farklılık olup olmadığına ilişkin analiz sonucu Tablo 5’te verilmiștir. 
Tablo 5. Deney ve kontrol gruplarının okul öncesi bilimsel süreç becerileri ölçeği ön test puanları arasındaki farklılı̆̆a ilişkin Mann-Whitney U testi sonuçları

\begin{tabular}{|c|c|c|c|c|c|c|c|}
\hline & & $\mathbf{N}$ & $\begin{array}{l}\text { S1ra } \\
\text { Ort. }\end{array}$ & $\begin{array}{l}\text { Sira } \\
\text { Top. }\end{array}$ & $\mathbf{z}$ & $\mathbf{U}$ & $\mathrm{p}$ \\
\hline \multirow{2}{*}{ Gözlem } & Deney Grubu & 19 & 21,39 & 406,50 & \multirow{2}{*}{$-1,308$} & \multirow{2}{*}{216,50} & \multirow{2}{*}{0,191} \\
\hline & Kontrol Grubu & 29 & 26,53 & 769,50 & & & \\
\hline \multirow{2}{*}{ Sinıflama } & Deney Grubu & 19 & 21,97 & 417,50 & \multirow{2}{*}{$-1,062$} & \multirow{2}{*}{227,50} & \multirow{2}{*}{0,288} \\
\hline & Kontrol Grubu & 29 & 26,16 & 758,50 & & & \\
\hline \multirow{2}{*}{ Tahmin Etme } & Deney Grubu & 19 & 17,97 & 341,50 & \multirow{2}{*}{$-2,741$} & \multirow{2}{*}{151,50} & \multirow{2}{*}{$0,006^{*}$} \\
\hline & Kontrol Grubu & 29 & 28,78 & 834,50 & & & \\
\hline \multirow{2}{*}{ Ölçme } & Deney Grubu & 19 & 16,79 & 319,00 & \multirow{2}{*}{$-3,228$} & \multirow{2}{*}{129,00} & \multirow{2}{*}{$0,001 *$} \\
\hline & Kontrol Grubu & 29 & 29,55 & 857,00 & & & \\
\hline \multirow{2}{*}{ Verileri Kaydetme } & Deney Grubu & 19 & 20,76 & 394,50 & \multirow{2}{*}{$-1,564$} & \multirow{2}{*}{204,50} & \multirow{2}{*}{0,118} \\
\hline & Kontrol Grubu & 29 & 26,95 & 781,50 & & & \\
\hline \multirow{2}{*}{ Sonuç Çıkarma } & Deney Grubu & 19 & 20,55 & 390,50 & \multirow{2}{*}{$-1,745$} & \multirow{2}{*}{200,50} & \multirow{2}{*}{0,081} \\
\hline & Kontrol Grubu & 29 & 27,09 & 785,5 & & & \\
\hline
\end{tabular}

${ }^{*} p<0,05$

Tablo 5'te analizler sonucunda Etkinlik Temelli STEM Eğitimi Uygulamalarına katılan deney grubundaki çocuklar ile uygulamaya katılmayan kontrol grubundaki çocukların; gözlem alt ölçeği ön test puanları arasinda istatistiksel olarak anlamlı bir farklılık yoktur, $U=216,50, p>0.05$. ( $z=-$ 1,308; $\mathrm{p}=0,191 ; \mathrm{p}>0,05)$. Sınıflama alt ölçeği ön test puanlanı arasında istatistiksel olarak anlamlı bir farklilık yoktur, $U=227,50, p>0,05$. ( $z=-1,062 ; p=0,288 ; p>0,05)$. Tahmin Etme alt ölçeği ön test puanları arasında istatistiksel olarak anlamlı bir farklılık vardır, $U=151,50, p>0,05 .(z=-2,741$; $\mathrm{p}=0,006 ; \mathrm{p}>0,05)$. Tahmin Etme becerisine ilişkin yapılan analizler sonucunda sıra ortalamaları dikkate alındığında söz konusu farklılık kontrol grubu çocuklarının lehinedir. Ölçme alt ölçeği ön test puanları arasında istatistiksel olarak anlamlı bir farklılık vardır, $U=129,00, p>0,05$. $(z=-3,228$; $\mathrm{p}=0,001 ; \mathrm{p}<0,05)$. Ölçme alt becerisine ilişkin yapılan analizler sonucunda sıra ortalamaları dikkate alındığında anlamlı farklılığın kontrol grubu çocukların lehine olduğu görülmektedir. Verileri Kaydetme alt ölçeği ön test puanları arasında istatistiksel olarak anlamlı bir farklılık yoktur, $\mathrm{U}=$ 204,50, $p>0,05 .(z=-1,564 ; p=0,118 ; p>0,05)$. Sonuç Çıkarma alt ölçeği ön test puanları arasında istatistiksel olarak anlamlı bir farkl1l1k yoktur, $U=200,50, p>0,05$. $(z=-1,745 ; p=0,081 ; p>0,05)$.

Tablo 5’teki verilere göre; deney ve kontrol gruplarının Okul Öncesi Bilimsel Süreç Becerileri Ölçeği ön test puanları arasındaki farklılığa ilişkin ölçeğin Tahmin ve Ölçme alt boyutlarında kontrol grubu çocukları lehine anlamlı farklılık olduğu bulgusuna ulaşılmıştır. Yarı deneysel desen kullanılan bu araştırmada deney ve kontrol grupları ön test puanlarının ölçeğin her bir alt boyutu için bakıldığında gözlem, sınıflama, verileri kaydetme ve sonuç çıkarma alt boyutlarında anlamlı farklılık olmadığ1 fakat tahmin ve ölçme alt boyutunda anlamlı farklılık olduğu yönündedir. Bu bulgu grupların uygulama öncesinde bu alt boyutlara ilişkin denk olmadığını göstermektedir. Fakat araştırmanın deseninde yarı deneysel desenlerden eşleştirilmemiş karşılaştırma grup desenine göre grupların belirlendiği belirtilmiştir (Christensen, Johnson ve Turner, 2011). Öyle ki, seçkisiz 
atamanın yapılmadığ yarı deneysel desenlerden eşleştirilmemiş desende, araştırmaya dahil edilen grupların denk olduğunu göstermez. Bu bağlamda; uygulamaların sonrasında öntest-son test uygulamaları karşılaştırılmasında bu farklılık dikkate alınarak yorumlar yapılması planlanmıştır.

Deney grubunda yer alan çocukların Etkinlik Temelli STEM Eğitimi Uygulamaları öncesinde ve sonrasında bilimsel süreç becerilerine anlamlı farklılık durumlarına ilişkin Wilcoxon İşaretli Sıralar Testi sonuçları Tablo 6'te verilmiştir.

Tablo 6. Deney grubu okul öncesi bilimsel süreç becerileri ölçeği ön test ve son test puanları arasındaki farkl1lığa ilişkin Wilcoxon İşaretli Sıralar testi sonuçları

\begin{tabular}{|c|c|c|c|c|c|}
\hline Deney Grubu & $\mathbf{N}$ & Siralar & S.O. & $z$ & $\mathrm{p}$ \\
\hline \multirow{4}{*}{ Gözlem } & 0 & Negatif Sira & 0,00 & $-3,855$ & $0,00^{*}$ \\
\hline & 19 & Pozitif Sira & 10,00 & & \\
\hline & 0 & Eşit & & & \\
\hline & 19 & Toplam & & & \\
\hline \multirow{4}{*}{ Siniflama } & 1 & Negatif Sira & 1,00 & $-3,820$ & $0,00 *$ \\
\hline & 18 & Pozitif Sıra & 10,50 & & \\
\hline & 0 & Eșit & & & \\
\hline & 19 & Toplam & & & \\
\hline \multirow{4}{*}{ Tahmin Etme } & 0 & Negatif Sira & 0,00 & $-3,848$ & $0,00 *$ \\
\hline & 19 & Pozitif Sıra & 10,00 & & \\
\hline & 0 & Eşit & & & \\
\hline & 19 & Toplam & & & \\
\hline \multirow{4}{*}{ Ölçme } & 0 & Negatif Sira & 0,00 & $-3,842$ & $0,00^{*}$ \\
\hline & 19 & Pozitif Sıra & 10,00 & & \\
\hline & 0 & Eşit & & & \\
\hline & 19 & Toplam & & & \\
\hline \multirow{4}{*}{ Verileri Kaydetme } & 0 & Negatif Sira & 0,00 & $-3,852$ & $0,00^{*}$ \\
\hline & 19 & Pozitif Sıra & 10,00 & & \\
\hline & 0 & Eșit & & & \\
\hline & 19 & Toplam & & & \\
\hline \multirow{4}{*}{ Sonuç Çıkarma } & 0 & Negatif Sira & 0,00 & $-3,871$ & $0,00^{*}$ \\
\hline & 19 & Pozitif Sıra & 10,00 & & \\
\hline & 0 & Eşit & & & \\
\hline & 19 & Toplam & & & \\
\hline
\end{tabular}

${ }_{\mathrm{p}}<0.05$

Tablo 6'da yapılan analizler sonucunda Etkinlik Temelli STEM Eğitim Uygulamalanna katılan çocukların; gözlem alt ölçeği son test puanları ön test puanları arasında anlamlı bir fark olduğunu göstermektedir ( $\mathrm{z}=-3,855 \mathrm{~s} ; \mathrm{p}=0,000 ; \mathrm{p}<0,05)$. Gözlem alt ölçeğine ilişkin fark puanlarının sıra ortalaması dikkate alındığında gözlenen bu farkın pozitif sıralar yani son test puanı lehine olduğu görülmektedir. Bu bulgulara göre uygulanan etkinlik temelli STEM eğitimi uygulamalarının deney grubu çocuklarının gözlem alt becerisine etkisi olduğu ve geliştirdiği söylenebilir. Sınıflama alt ölçeği son test puanları ön test puanları arasında anlamlı bir fark olduğunu göstermektedir $(z=-3,820$ s; $\mathrm{p}=0,000 ; \mathrm{p}<0,05) . \mathrm{Bu}$ farkın son test puanı lehine olduğu görülmektedir. Bu bulgulara göre uygulanan etkinlik temelli STEM eğitimi uygulamalarının deney grubu çocuklarının sınıflama alt becerisine etkisi olduğu ve geliştirdiği söylenebilir. Tahmin Etme alt ölçeği son test puanları ön test 
puanları arasında anlamlı bir fark olduğunu göstermektedir $(\mathrm{z}=-3,848 ; \mathrm{p}=0,00 ; \mathrm{p}<0,05)$. Bu farkın pozitif sıralar yani son test puanı lehine olduğu görülmektedir. Bu bulgulara göre uygulanan etkinlik temelli STEM eğitimi uygulamalarının deney grubu çocuklarının tahmin etme alt becerisine etkisi olduğu ve geliştirdiği söylenebilir. Ölçme alt ölçeği son test puanları ön test puanları arasında anlamlı bir fark olduğunu göstermektedir $(\mathrm{z}=-3,842 ; \mathrm{p}=0,00 ; \mathrm{p}<0,05)$. Bu farkın son test puanı lehine olduğu görülmektedir. Bu bulgulara göre uygulanan etkinlik temelli STEM eğitimi uygulamalarının deney grubu çocuklarının ölçme alt becerisine etkisi olduğu ve geliştirdiği söylenebilir. Verileri Kaydetme alt ölçeği son test puanları ön test puanları arasında anlamlı bir fark olduğunu göstermektedir ( $z=-3,852 ; p=0,00 ; p<0,05)$. Bu farkın pozitif sıralar yani son test puanı lehine olduğu görülmektedir. Bu bulgulara göre uygulanan etkinlik temelli STEM eğitimi uygulamalarının deney grubu çocuklarının verileri kaydetme alt becerisine etkisi olduğu ve geliştirdiği söylenebilir. Sonuç Çıkarma alt ölçeği son test puanları ön test puanları arasında anlamlı bir fark olduğunu göstermektedir $(\mathrm{z}=-3,871 ; \mathrm{p}=0,00 ; \mathrm{p}<0,05)$. Bu farkın son test puanı lehine olduğu görülmektedir. Bu bulgulara göre uygulanan etkinlik temelli STEM eğitimi uygulamalarının deney grubu çocuklarının sonuç çıkarma alt becerisine etkisi olduğu ve geliştirdiği söylenebilir.

Kontrol grubunda yer alan çocukların Etkinlik Temelli STEM Eğitimi Uygulamaları öncesi ve sonrası bilimsel süreç becerilerinin anlamlı farklılık gösterip göstermediğine ilişkin Wilcoxon İşaretli Sıralar Testi sonuçları Tablo 7'de verilmiştir.

Tablo 7. Kontrol grubu okul öncesi bilimsel süreç becerileri ölçeği ön test ve son test puanları arasındaki farklılığa ilișkin Wilcoxon İşaretli Sıralar testi sonuçları

\begin{tabular}{|c|c|c|c|c|c|}
\hline Kontrol Grubu & $\mathbf{N}$ & S1ralar & S.O. & $z$ & $p$ \\
\hline \multirow{4}{*}{ Gözlem } & 14 & Negatif Sira & 11,36 & $-2,149$ & 0,32 \\
\hline & 6 & Pozitif Sira & 8,50 & & \\
\hline & 9 & Eşit & & & \\
\hline & 29 & Toplam & & & \\
\hline \multirow{4}{*}{ Siniflama } & 5 & Negatif Sira & 12,50 & $-1,336$ & 0,182 \\
\hline & 14 & Pozitif Sira & 9,11 & & \\
\hline & 10 & Eșit & & & \\
\hline & 29 & Toplam & & & \\
\hline \multirow{4}{*}{ Tahmin Etme } & 20 & Negatif Sira & 11,63 & $-3,505$ & $0,00^{*}$ \\
\hline & 2 & Pozitif Sira & 10,25 & & \\
\hline & 7 & Eşit & & & \\
\hline & 29 & Toplam & & & \\
\hline \multirow[b]{8}{*}{ 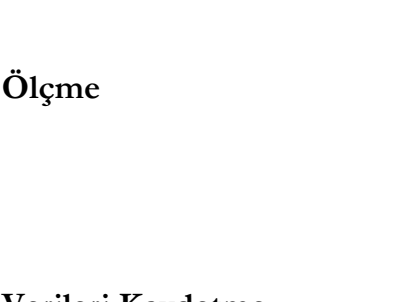 } & 12 & Negatif Sira & 11,25 & $-2,220$ & $0,026^{*}$ \\
\hline & 6 & Pozitif Sıra & 6,00 & & \\
\hline & 11 & Eşit & & & \\
\hline & 29 & Toplam & & & \\
\hline & 10 & Negatif Sira & 8,40 & $-0,452$ & 0,651 \\
\hline & 9 & Pozitif Sira & 11,78 & & \\
\hline & 10 & Eşit & & & \\
\hline & 29 & Toplam & & & \\
\hline
\end{tabular}




\begin{tabular}{lccccc}
\cline { 5 - 6 } & & & & & \\
& 11 & Negatif Sira & 8,91 & $-2,263$ & $0,024^{*}$ \\
Sonuç Ç1karma & 4 & Pozitif Sıra & 5,50 & & \\
& 14 & Eşit & & \\
\hline
\end{tabular}

${ }^{*} \mathrm{p}<0.05$

Tablo 7'de yapılan analizler sonucunda Etkinlik Temelli STEM Eğitimi Uygulamalarına katılmayan çocukların; gözlem alt ölçeği son test puanları ön test puanları arasında istatistiksel olarak anlamlı bir farklılık yoktur $(\mathrm{z}=-2,149 ; \mathrm{p}=0,32 ; \mathrm{p}>0,05)$. Sinıflama alt ölçeği son test puanları ön test puanları arasinda istatistiksel olarak anlamlı bir farklılık yoktur $(z=-1,336$; $\mathrm{p}=0,182 ; \mathrm{p}>0,05)$. Tahmin Etme alt ölçeği son test puanları ön test puanları arasında istatistiksel olarak anlamlı bir farklılık vardır $(\mathrm{z}=-3,505 ; \mathrm{p}=0,00 ; \mathrm{p}<0,05)$. Tahmin Etme alt ölçeğine ilişkin fark puanlarının sıra ortalaması dikkate alındığında gözlenen bu farkın negatif sıralar yani ön test puanı lehine olduğu görülmektedir. Ölçme alt ölçeği son test puanları ön test puanları arasında istatistiksel olarak anlamlı bir farklılık vardır $(z=-2,220 ; p=0,026 ; p<0,05)$. Ölçme alt ölçeğine ilişkin fark puanlarının sıra ortalaması dikkate alındığında gözlenen bu farkın negatif sıralar yani ön test puanı lehine olduğu görülmektedir. Verileri Kaydetme alt ölçeği son test puanları ön test puanları arasında istatistiksel olarak anlamlı bir farklılık yoktur ( $\mathrm{z}=-0,452 ; \mathrm{p}=0,651 ; \mathrm{p}>0,05)$. Sonuç Çıkarma alt ölçeği son test puanları ön test puanları arasında istatistiksel olarak anlamlı bir farklılık vardır $(\mathrm{z}=-2,263$; $\mathrm{p}=0,024 ; \mathrm{p}<0,05)$. Sonuç Çıkarma alt ölçeğine ilişkin fark puanlarının sıra ortalaması dikkate alındığında gözlenen bu farkın negatif sıralar yani ön test puanı lehine olduğu görülmektedir. Tahmin etme, ölçme ve sonuç çıkarma alt ölçeklerinde hesaplanan anlamlı farklılı̆̆ın, sınıf öğretmeninin uyguladığı etkinlikler, çevresel etkenler ve aile katılımının neden olduğu düşünülebilir.

Deney ve kontrol grubunda yer alan çocukların Etkinlik Temelli STEM Eğitimi Uygulamaları sonunda okul öncesi bilimsel süreç becerileri ölçeği son test puanlarının anlamlı farklılık gösterip göstermediğine ilişkin Mann-Whitney U testi sonuçları Tablo 8'de verilmiştir.

Tablo 8. Deney ve kontrol gruplarının okul öncesi bilimsel süreç becerileri ölçeği son test puanları arasındaki farklılığına ilişkin Mann-Whitney U testi sonuçları

\begin{tabular}{|c|c|c|c|c|c|c|c|c|}
\hline \multicolumn{2}{|c|}{ Son Test } & $\mathbf{N}$ & $\begin{array}{l}\text { S1ra } \\
\text { Ort. }\end{array}$ & $\begin{array}{l}\text { Sira } \\
\text { Top. }\end{array}$ & $\mathbf{z}$ & $\mathbf{U}$ & $\mathrm{p}$ & $\eta^{2}$ \\
\hline \multirow{2}{*}{ Gözlem } & Deney Grubu & 19 & 39,00 & 741,00 & \multirow{2}{*}{$-5,917$} & \multirow{2}{*}{0,00} & \multirow{2}{*}{$0,00^{*}$} & \multirow[t]{2}{*}{$-0,85$} \\
\hline & Kontrol Grubu & 29 & 15,00 & 435,00 & & & & \\
\hline \multirow{2}{*}{ Siniflama } & Deney Grubu & 19 & 38,79 & 737,00 & \multirow{2}{*}{$-5,843$} & \multirow{2}{*}{4,00} & \multirow{2}{*}{$0,00^{*}$} & \multirow[t]{2}{*}{$-0,84$} \\
\hline & Kontrol Grubu & 29 & 15,14 & 439,00 & & & & \\
\hline \multirow{2}{*}{ Tahmin Etme } & Deney Grubu & 19 & 39,00 & 741,00 & \multirow{2}{*}{$-5,887$} & \multirow{2}{*}{0,00} & \multirow{2}{*}{$0,00^{*}$} & \multirow[t]{2}{*}{$-0,84$} \\
\hline & Kontrol Grubu & 29 & 15,00 & 435,00 & & & & \\
\hline \multirow{2}{*}{ Ölçme } & Deney Grubu & 19 & 39,00 & 741,00 & \multirow{2}{*}{$-6,226$} & \multirow{2}{*}{0,00} & \multirow{2}{*}{$0,00^{*}$} & \multirow[t]{2}{*}{$-0,89$} \\
\hline & Kontrol Grubu & 29 & 15,00 & 435,00 & & & & \\
\hline Verileri & Deney Grubu & 19 & 39,00 & 741,00 & \multirow{2}{*}{$-5,894$} & \multirow{2}{*}{0,00} & \multirow{2}{*}{$0,00 *$} & \multirow[t]{2}{*}{$-0,85$} \\
\hline \multirow[t]{2}{*}{ Kaydetme } & Kontrol Grubu & 29 & 15,00 & 435,00 & & & & \\
\hline & & & & $\begin{array}{l}\text { Journ } \\
\text { Volur }\end{array}$ & $\begin{array}{l}\text { arly Child } \\
\text { sue } 1 \cdot A\end{array}$ & & & \\
\hline
\end{tabular}




\begin{tabular}{lllllllll}
\multirow{2}{*}{ Sonuç Çıkarma } & Deney Grubu & 19 & 38,63 & 734,00 & $-5,807$ & 7,00 & $0,00 *$ & $-0,83$ \\
\hline $\mathrm{p}<0.05$ & Kontrol Grubu & 29 & 15,24 & 442,00 & -50 &
\end{tabular}

Tablo 8'de yapılan analizler sonucunda Etkinlik Temelli STEM Eğitim Uygulamalarına katılan çocuklar ile böyle bir uygulamaya katılmayan çocukların; Gözlem alt ölçeği son test puanları arasında istatistiksel olarak anlamlı bir farklılık vardır: $U=0,00, p<0.05$. $(z=-5,917 ; p=0,00 ; p<0,05)$. Gözlem alt becerisine ilişkin sıra ortalamaları dikkate alındığında, Etkinlik Temelli STEM Eğitimi Uygulamalarına katılan çocuklar lehine olduğu belirlenmiştir. Sınıflama alt ölçeği son test puanları arasında istatistiksel olarak anlamlı bir farklılık vardır: $U=4,00, p<0.05$. $(z=-5,843 ; p=0,00 ; p<0,05)$. Sınıflama alt becerisine ilişkin sıra ortalamaları dikkate alındığında, Etkinlik Temelli STEM Eğitimi Uygulamalarına katılan çocuklar lehine olduğu belirlenmiştir. Tahmin Etme alt ölçeği son test puanları arasında istatistiksel olarak anlamlı bir farklılık vardır: $U=0,00, p<0.05$. $(z=-5,887 ; p=0,00$; $\mathrm{p}<0,05)$. Tahmin Etme alt becerisine ilişkin sıra ortalamaları dikkate alındığında, Etkinlik Temelli STEM Eğitimi Uygulamalarına katılan çocuklar lehine olduğu belirlenmiştir. Ölçme alt ölçeği son test puanları arasında istatistiksel olarak anlamlı bir farklılık vardır: $U=0,00, p<0.05$. ( $\mathrm{z}=-6,226$; $\mathrm{p}=0,00 ; \mathrm{p}<0,05)$. Ölçme alt becerisine ilişkin sıra ortalamaları dikkate alındığında, Etkinlik Temelli STEM Eğitimi Uygulamalarına katılan çocuklar lehine olduğu belirlenmiştir. Verileri Kaydetme alt ölçeği son test puanları arasında istatistiksel olarak anlamlı bir farklılık vardır: $U=0,00, p<0.05$. $(\mathrm{z}=-5,894 ; \mathrm{p}=0,00 ; \mathrm{p}<0,05)$. Verileri Kaydetme alt becerisine ilişkin sıra ortalamaları dikkate alındığında, Etkinlik Temelli STEM Eğitimi Uygulamalarına katılan çocuklar lehine olduğu belirlenmiştir. Sonuç Çıkarma alt ölçeği son test puanları arasında istatistiksel olarak anlamlı bir farklılık vardır: $U=7,00, p<0.05$. ( $z=-5,807 ; p=0,00 ; p<0,05)$. Sonuç Çıkarma alt becerisine ilişkin sıra ortalamaları dikkate alındığında, Etkinlik Temelli STEM Eğitimi Uygulamalarına katılan çocuklar lehine olduğu belirlenmiştir. Belirlenen sonuçlara göre etki büyüklüklerine $\left(\eta^{2}\right)$ bakıldığında, gözlem alt becerisinde $\left(\eta^{2}=-.85\right)$, sinıflama becerisinde $\left(\eta^{2}=-.84\right)$, tahmin etme becerisinde $\left(\eta^{2}=-.84\right)$, ölçme becerisinde $\left(\eta^{2}=-.89\right)$, verileri kaydetme becerisinde $\left(\eta^{2}=-.85\right)$ ve sonuç çıkarma becerisinde $\left(\eta^{2}=-.83\right)$ olduğu belirlenmiştir. Bu veriler alt becerilerin büyük etki büyüklügüne sahip olduğuna işaret etmektedir (Köklü, Büyüköztürk ve Bökeoğlu, 2006).

\section{SONUÇ ve TARTIŞMA}

Deney grubunda yer alan çocukların Okul Öncesi Bilimsel Süreç Becerileri Ölçeği ve alt ölçeklerinin ön test ve son test puanları arasındaki farklılı̆̆ına ilişkin sonuca göre; etkinlik temelli STEM eğitimi uygulamalarına katılan çocukların Gözlem, Sınıflama, Tahmin Etme, Ölçme, Verileri Kaydetme, Sonuç Çıkarma son test puanları ile ön test puanları arasında anlamlı bir farklılık olduğunu 
göstermektedir. Deney grubunda yer alan çocukların katıldıkları ilgili eğitim etkinliklerine bağlı olarak son test bilimsel süreç becerileri puanlarında önemli bir artışı olduğu sonucuna ulaşılmıştır.

Etkinlik Temelli STEM Eğitimi Uygulamaları uygulanan deney grubu çocuklarının ölçeğin alt boyutları gözlem, sınıflama, tahmin etme, ölçme, veri kaydetme, sonuç çıkarma becerileri ön testson test puanları arasında anlamlı farklılık ortaya çıkmıştır. Etkinlik Temelli STEM Eğitimi Uygulamaları çocukların bilimsel süreç becerilerine pozitif katkı sağlamıştır, bu sonucun nedeni Etkinlik Temelli STEM Eğitimi Uygulamaları olduğu düşünülebilir. Bu uygulamalarda çocukların yaparak yaşayarak, aktif katılımın sağlandığı işbirlikli grup çalışması ile etkinliklerini tamamlamışardır. Bu araştırmada Etkinlik Temelli STEM Eğitiminin çocukların Bilimsel Süreç Becerilerine olan anlamlı farklılığa yönelik sonuçları ile okul öncesi dönemde STEM eğitimi uygulamaları kullanılarak çocukların bilimsel süreç becerilerini desteklediği (Bal, 2018; Günşen, Fazlıŏlu ve Bayır, 2017; Öcal, 2018) sonuçları ile paralellik gösterdiği söylenebilir. Bu bağlamda yapılan araştırmalara bakıldığında bilimsel süreç becerileriyle ilgili olarak verilecek uygun etkinlik uygulamaları ile çocukların bilimsel süreç becerilerinin gelişebileceği sonucu ortaya çıkmaktadır.

Fen öğretiminde bu dönemdeki çocukların yaparak-yaşayarak öğrenmesinin ve etkinlik materyallerinin somut nesneler üzerinde gözlemlemeleri çocukların bilimsel süreç becerileri yönünden önemli olduğu belirtilmiştir (Chittleborough, Treagust, Mamiala and Mocerino, 2005). Öyle ki bu araştırmanın sonuçlarından biri de uygulanan etkinliklerin bilimsel süreç becerileri üzerine etkisi olduğu şeklindedir. Bunun 1şı̆̆ında; Etkinlik Temelli STEM Eğitimi Uygulamalarındaki etkinlik uygulamalarına tüm çocukların aktif biçimde katılarak yaparak-yaşayarak öğrenme, özgürce seçim yapabilme hem görsel hem işitsel materyallerin kullanımı vb. sonucu olarak ortaya ç1ktı̆̆1 söylenebilir.

Bilimsel süreç becerilerinde ilk boyut olan gözlem becerisine yönelik deney grubuna uygulanan etkinlik temelli STEM eğitimi uygulamalarında kullanılan etkinlikler, etkinliklerde kullanılan materyaller, tasarım odaklı düşünme, somut nesneleri gözlemleme, etkinliklerde kullanılan anlatım, grup çalışması ve beyin firtınası gibi yöntem ve tekniklerin etkili olduğu düşünülmektedir. Etkinliklerde araştırmacı tarafindan "Sizce burada bir problem durum var mı?, Buradaki problem durumu nasıl çözebiliriz?, Neler geliştirmeliyiz? Tasarımın hangi özelliklerine dikkat etmeliyiz? Amacına ulaşmayan tasarımlarda hangi değişiklikleri yapmalıyız?" şeklinde sorular sorulmuştur. Örneğin bir etkinlikte araştırmacı, farklı tasarımlarda ve malzemelerden yapılmış mancınık fotoğrafları göstermiştir. Araştırmacı tarafından gösterilen fotoğraflardaki mancınıkları çocukların gözlemlemeleri sağlanmıştır. Bilgiyi yapılandırmada gözlem becerisinin önemli olduğundan 
hareketle (Haslam ve Gunstone, 1996), çocukların etkinliklerde gerçek yaşama dayalı, çocuk merkezli öğretim yapılması, etkinliğin tüm sürecini çocuğun görerek, yaparak izlemesi gözlem becerisini kazanmasında olumlu etkilediği düşünülmektedir. Ayrıca benzer olarak literatürde farklı uygulamalar ve eğitim-öğretim teknikleriyle çocukların bilimsel süreç becerilerinden gözlem becerisini kazandığının bu sonucu destekler nitelikte olduğu görülmektedir (Alabay ve Özdoğan, 2018; Büyüktaşkapu, 2010; Civelek ve Akamca, 2018; Karataş, 2018; Sağ1rekmekçi, 2016; Tekerci ve Kandır, 2017; Toprakkaya, 2016; Şahin, Güven ve Yurdatapan, 2011).

$\mathrm{Bu}$ araştırmada çocuklara davranışları kazandırmak için STEM eğitimi uygulamalarında sıklıkla sınıflama yapma imkânı sunulmuştur. Sınıflama becerisi son test puan ortalamaları karşılaştırıldığında deney grubundaki çocukların son test puan ortalamaları kontrol grubundaki çocukların son test puan ortalamalarından anlamlı düzeyde yüksektir. Çocuklar bulundukları gelişim düzeyine göre sınıflama yaparlar ve yaşları arttıkça yapılan sınıflamaların düzeyleri de artmaktadır (Büyüktaşkapu, 2010; Kumtepe, Kaya ve Kumtepe, 2009). Sınıflama becerisi çocukların yaptıkları etkinliklerden, oyunlarından ve koleksiyonlarından etkilenmekte, ilerlemekte olduğu düşünüldüğünde (Akman, Üstün ve Güler, 2003) örneğin “Legoları Sepete Koyalım” etkinliğinde çocuklardan farklı renkte, şekilde, cinste legoları gruplandırmak için sepet tasarımı yapmaları istenmiştir. Çocukların sepet tasarlarken tek bir sınıflamadan çok birden fazla özelliği içeren sınıflamalar yapmaları istenmiştir. Etkinlik sonunda hangi özellikleri dikkate alarak sınıflama yaptıkları, bunun için sepet tasarımlarında nelere dikkat ettikleri ve amaca hizmet etmeyen tasarımları düzeltmede değerlendirmelerde bulunulmuştur. Çocukların legoları sınıflamasında ilk önce rengine göre daha sonra şekline göre sınıflama yaptıkları araştırmacı tarafından tespit edilmiştir. Diğer etkinlik uygulamasında atık materyallerden halı yaparken kullanılacak malzemeleri etkinlik amacına uygun sınıflama/lar yapmaları beklenmiştir. Malzemelerin yapıldığı maddeler, dokusu, sağlamlığı, rengi, büyüklüğü, kokusu gibi özellikleri göz önünde bulundurularak çocuklar sınıflamalar yapmışlardır. Yaptıkları tasarıma uygun olarak, sağlam ve sert malzemeleri halı yapımı için kullanmışlardır ve parlak, hafif ve yumuşak malzemeleri daha çok süslemek için kullanmayı tercih etmişlerdir. Ayrıca bir diğer etkinlikte yüzen bir araç tasarlayan çocuklar etkinlik malzemeleri olarak yüzen ve batan cisimleri sınıflamışlardır. Tasarımlarına uygun yüzen araçlar yapmak için gerekli malzemeleri belirleyip, aracı yapıp test etmişlerdir. Batan araçlar belirlenip, yanlışs seçilmiş malzemeler tespit edilmiş ve hatalı adımlar düzeltilmiştir. Öyle ki, çocukların sınıflama becerisini destekleyen başka bir etkinlikte bez çanta tasarlamışlardır. Bez çantaları için seçtikleri atık malzemeleri sınıflama yapıp, etkinliğin farklı adımlarında kullanmışlardır. Bez çantaların içine kitaplar, legolar ve oyuncaklar vb. koyularak (standart olmayan ölçme) sınıfta eşyalar taşınmıştır. Test edildikten sonra hatalı adımlar çocuklarla belirlenmiştir. Alan yazın incelendiğinde benzer 
sonuçlara ulaşıldığ1 görülmektedir. Alabay (2013) ScienceStart ${ }^{\mathrm{TM}}$ destekli fen eğitim programıyla çocukların bilimsel süreç becerilerini desteklemiştir. Deney grubunun ön test-son test puan ortalamaları incelendiğinde çocukların bilimsel süreç becerilerinden sınıflama becerisinin anlamlı farklılaştığını bulmuştur. Özkan (2015) çalışmasında beyin temelli öğrenmeye dayanan fen programının çocukların bilimsel süreç becerilerine etkisini incelemiştir. Uygulanan programın çocukların sınıflama becerisi puanlarını anlamlı düzeyde yükselttiği tespit edilmiştir. Toprakkaya (2016) araştırmasında 55-72 aylık çocuklara dış alanda sorgulama tabanlı bilim etkinlikleri uygulamış ve bilimsel süreç becerilerine etkisini incelemiştir. Deney grubun çocuklarının sınıflama becerisinin bilim etkinlikleri ile anlamlı düzeyde yükseldiği ifade edilebilir.

Çocuklara kazandırılması hedeflenen bilimsel süreç becerilerinin üçüncü boyutu tahmin etmedir. Yetişkinler gibi çocukların da araştırmalarında gözlemler yaptıkları, hassas ölçümlere ve gözlemledikleri hakkında çıkarımlara dayandırdıkları tahminlerde bulunurlar (Büyüktaşkapu, 2010). Etkinlik temelli STEM eğitimi uygulamalarında sıklıkla çocukların tahmin etmelerini destekleyen etkinlikler yapılmıştır. Tahmin etme becerisi son test puan ortalamaları karşılaştırıldığında deney grubundaki çocukların son test puan ortalamaları kontrol grubundaki çocukların son test puan ortalamalarından anlamlı düzeyde yüksektir. Örneğin bir etkinlikte, çocukların hafif ve ağır nesneleri tahmin etmeleri istenmiş ve grafik olușturmaları sağlanmıştır. Müzik aletleri yapımı ile ilgili diğer etkinlikte çocukların gözü kapalı olarak çıkan seslerin hangi müzik aletinden çaldığını tahmin etmeleri sağlanmıştır. Kullanılan ölçekte eğim ve sarkaç etkinliklerinde araştırmacı tarafindan çocukların tahmin etme becerisini geliştirdikleri gözlenmiştir. Alan yazın incelendiğinde Büyüktaşkapu, Çeliköz ve Akman (2012) çalışmasında yapılandırmacı bilim eğitimi programıyla 6 yaş çocuklarının bilimsel süreç becerilerini araştırmışlardır. Yapılan ölçümler sonucunda deney grubundaki çocukların tahmin etme becerisi puanları anlamlı düzeyde artış göstermiştir. Tekerci ve Kandır (2017) araştırmasında 48-66 aylık çocuklara duyu temelli bilim eğitimi programı uygulamış ve bilimsel süreç becerilerine etkisini incelemiștir. Elde edilen bulgulara göre eğitim programı çocukların tahmin etme becerisini desteklemektedir.

Etkinlik temelli STEM eğitimi uygulamalarında çocukların ölçme becerisini kazanmaları desteklenmiştir. Ölçme becerisi son test puan ortalamaları karşılaştırıldığında deney grubundaki çocukların son test puan ortalamaları kontrol grubundaki çocukların son test puan ortalamalarından anlamlı düzeyde yüksektir. Aykut (2006)'a göre, okul öncesi öğretmenlerinin bilimsel süreç becerilerinden ölçme becerisine diğer becerilerden daha az yer verdiklerini tespit etmiştir. Etkinlik temelli STEM eğitimi uygulamalarında standart olmayan birimlerle ölçümler yapılmıştır. Bir etkinlikte tasarımı çocuklara ait kuleler yapıldıktan, sınıfça belirlenen bir malzeme kullanılarak 
ölçüm yapılmıştır. Bir başka etkinlikte çocukların tasarlayıp yaptıkları köprüleri standart olmayan bir malzeme ile sağlamlığı ölçülmüştür. Karataş (2018) çalışmasında İlk Yıllar Programı'nın çocukların bilimsel süreç becerilerine etkisini incelemiş ve ölçme becerisinin desteklendiğini tespit etmiştir.

Bilimsel süreç becerilerinden kazanılması hedeflenen diğer beceri ise verileri kaydetmedir. Verileri kaydetme becerisi son test puan ortalamaları karşılaştırıldığında deney grubundaki çocukların son test puan ortalamaları kontrol grubundaki çocukların son test puan ortalamalarından anlamlı düzeyde yüksektir. Okul öncesi çocuklarının verileri kaydetme becerisiyle elde ettikleri bilgileri akranlarıla ve diğer insanlarla paylaşması önemlidir. Okul öncesi dönemde verileri kaydetme becerisi resimler çizerek, grafikler oluşturarak, fotoğraflar çekerek ve elde ettiği bilgileri sunarak kazanmasını içermektedir (Büyüktaşkapu, 2010; NRC, 1996). Bu araştırmada yapılan etkinliklerde verileri kaydetme becerisi desteklenmesi amaçlanarak hazırlanan müzik aletlerinin çıkardıkları sesin uzaklığını grafik oluşturarak kaydedilmiştir. Bir başka etkinlikte yenebilir malzemeler yapılan araçların gittikleri mesafeler yine çocuklar tarafindan kaydedilmiştir. Çocuklar algoritmaları kullandığ1 etkinlikte, "Flurb" lerin gidecekleri yönü belirlemişler ve sonuçları kaydetmişlerdir. Büyüktaşkapu, Çeliköz ve Akman (2012) araştırmasında yapılandırmacı bilim eğitimi programıyla deney grubu çocuklarının verileri kaydetme becerisinin anlamlı düzeyde yüksek olduğunu tespit etmiştir. Toprakkaya (2016) çalısmasında, sorgulama tabanlı bilim etkinliklerinin çocukların verileri kaydetme becerisinin anlamlı düzeyde yükseldiğini ortaya koymuştur.

Etkinlik temelli STEM eğitimi uygulamalarında temel bilimsel süreç becerilerinden son olarak sonuç çıarma becerisini kazanmaları hedeflenmektedir. Sonuç çıkarma becerisi son test puan ortalamaları karşılaştırıldığında deney grubundaki çocukların son test puan ortalamaları kontrol grubundaki çocukların son test puan ortalamalarından anlamlı düzeyde yüksektir. Çocuklar araştırmalar yaparken önceden öğrendikleri bilgileri ile deneyimledikleri yeni bilgileri karşılaştırıp, yorumlayıp yeni çıkarımlarda bulunacaklardır. Örneğin bir etkinlikte mühendislik tasarım sürecinden faydalanarak saksı yapılmıştır. Çocuklar tasarımda amaca uygun çıkarımlarda bulunması ve değerlendirme için eğitimci tarafından güdülenmiştir. Ölçek uygulanırken yapılan silindir ve su etkinliklerinde sonuç çıkarma becerisinin desteklendiği araştırmacı tarafından gözlemlenmiştir. Büyüktaşkapu, Çeliköz ve Akman (2012) araştırmasında deney grubu çocuklarına temel bilimsel süreç becerilerinden sonuç çıkarma becerisinin yapılandırmacı bilim eğitimi programıyla kazanıldığını tespit etmiştir. Sorgulama tabanlı bilim etkinlikleri çocukların bilimsel süreç becerilerini inceleyen Toprakkaya (2016) çalışmasında deney grubu çocuklarının sonuç çıkarma becerisinde anlamlı farklılık tespit etmiştir. 
Kontrol grubunda yer alan çocukların Okul Öncesi Bilimsel Süreç Becerileri Ölçeği ön test ve son test puanları arasındaki farklılı̆̆ına ilişkin sonuca göre; çocukların Tahmin Etme, Ölçme, Sonuç Çıkarma alt ölçeğine ilişkin ön test ve son test puanları arasında istatistiksel olarak anlamlı bir fark olmasına rağmen; Gözlem, Sınıflama, Verileri Kaydetme alt ölçeğinden aldıkları ön test ve son test puanları incelendiğinde, ön test ve son test puanları arasında istatistiksel olarak anlamlı bir farkın olmadığ1 görülmektedir. Ancak kontrol grubunda Tahmin Etme, Ölçme, Sonuç Çıkarma alt ölçeğine ilişkin anlamlı farkın son test lehine olduğu görülmektedir. Bu anlamlı farklılığın nedeni ise günlük planda söz konusu bilimsel süreç becerilerinin kazanılmasına yönelik etkinliklerin yer alma durumlarının yetersizliği/eksikliği ve diğer dışsal faktörlerin (öğretmenin fen etkinlikleri yapması, fene yönelik tutumu, okul dışı öğrenme ortamlarının etkisi, aile vb.) etkileyebileceği gibi durumlar olarak düşünülebilir. Büyüktaşkapu, Çeliköz ve Akman'ın (2012) çalısmasında, kontrol grubu çocuklarının öntest- sontest puanları karşılaştırıldığında gözlem, sınıflama ve sonuç çıkarma alt boyutlarında anlamlı farklılık tespit edilmiştir. Bu bulgular araştırmanın bulguları ile paralellik göstermektedir.

Bu araştırmada deney ve kontrol gruplarındaki çocukların benzer gelişim dönemlerinde yer almaları, aynı okulda benzer fiziksel ortamlarda öğrenim görmeleri, benzer sosyoekonomik duruma sahip olmalarının yanında gruplardaki çocuk sayılarının denk olmayıșı ve bu araștırmada cinsiyet faktörünün de bir değişken olarak araştırmaya dahil edilmemesi araştırmanın sınırlılığı olarak düşünülebilir. Bunlar 1şığında deney ve kontrol grubunda yer alan çocukların ölçek ve alt ölçeklerinin son test puanları arasındaki farklılığına ilişkin sonuca göre; Etkinlik Temelli STEM Eğitimi Uygulamalarına katılan çocuklar ile böyle bir uygulamaya katılmayan çocukların ölçeğin alt boyutlarının son test puanlarının ortalamalarına bakıldığında, deney grubundaki çocukların puan ortalamaları kontrol grubundaki çocukların puan ortalamalarından daha yüksek olduğu görülmektedir. Buna göre; Etkinlik Temelli STEM Eğitimi Uygulamalarının çocukların bilimsel süreç becerilerini olumlu yönde desteklediği sonucuna ulaşılmaktadır.

Bu araştırmanın sonuçlarına dayalı olarak; STEM etkinlik uygulamalarının çocukların bilimsel süreç becerilerine etkisinin olduğundan hareketle okul öncesi öğretmenlerinin STEM yaklaşımına dayalı etkinlik uygulamaları dahil edebilmelerinin önerilebilir. Buradan hareketle okul öncesi öğretmenlerine seminer dönemlerinde STEM yaklaşımına ait hizmet içi eğitim verilmesi önerilebilir.

\section{KAYNAKÇA}

Akçay, B. (2019). STEM etkinliklerinin anaokuluna devam eden 6 yas çocuklarm problem çöæme becerilerine etkisi. Yayımlanmamış Yüksek lisans tezi. Yıldız Teknik Üniversitesi, İstanbul. 
Akgündüz, D., \& Akpınar, B. C. (2018). Okul Öncesi Eğitiminde Fen Eğitimi Temelinde Gerçekleștirilen STEM Uygulamalarının Öğrenci, Öğretmen ve Veli Açısından Değerlendirilmesi. Yaşadıkşa Eğitim Dergisi, 32(1), 1-26.

Akman, B., Üstün, E., \& Güler, T. (2003). 6 yaş çocuklarının bilimsel süreçlerini kullanma yetenekleri. Hacettepe Üniversitesi Eğitim Fakültesi Dergisi, 24, 11-14.

Alabay, E. (2013). Sciencestart! ${ }^{T M}$ destekli fen eğitim programmm 60-72 ayllk çocuklarn bilimsel sürec becerilerine ve bilimsel tutuma güvenme ve yönelme etkisi. Doktora Tezi, Selçuk Üniversitesi Sosyal Bilimler Enstitüsü, Konya.

Alabay, E., \& Özdoğan, İ. M. (2018). Okulöncesi Çocuklara Dış Alanda Uygulanan Sorgulama Tabanlı Bilim Etkinliklerinin Bilimsel Süreç Becerilerine Etkisinin Incelenmesi. Trakya Üniversitesi Eğitim Fakültesi Dergisi, 8(3), 481-496.

Alan, Ü. (2020). Okul Öncesi Dönem Cocuklarna Yönelik Gelistirilen STEM Ë̆itimi Programmmn Etkililiğinin Incelenmesi. Yayımlanmamıs Doktora Tezi. Hacettepe Üniversitesi, Ankara.

American Association for the Advancement of Science AAAS (1993). Benchmarks for Science literacy. New York: Oxford University Press. 06.05.2020 tarihinde http://www.project2061.org/publications/bsl/online/index.php?home=true adresinden erişilmiştir.

Andersson, K., \& Gullberg, A. (2014). What is science in preschool and what do teachers have to know to empower children?. Cultural studies of science education, 9(2), 275-296. DOI: $10.1007 /$ s11422-012-9439-6.

Ata-Aktürk, A. (2019). Development of a STEM based engineering design curriculum for parental involvement in early childhood education (Doctoral dissertation). Middle East Technical University, Ankara.

Atik, A. (2019). STEM etkinliklerinin bilimsel süreç becerileri üzerine etkisi: 5 yaș örneğgi. Yayımlanmamıș Yüksek lisans tezi. Trabzon Üniversitesi, Trabzon.

Aydın, T. (2019). STEM uygulamalarmın okul öncesi ögrencilerinin bilimsel süreç becerileri ve bilisssel alan gelisimlerine etkisi. Yayımlanmamış Yüksek lisans tezi. Fırat Üniversitesi, Elazığ.

Aykut, Ö. (2006). Baž değişkenlerin okul öncesi eğitimi öğretmenlerinin fen ve doğa çalısmalarna ilişkin görüslerine etkisi. Yayımlanmamış Yüksek Lisans Tezi. Gazi Üniversitesi Eğitim Bilimleri Enstitüsü. Ankara.

Ayvac1, H. Ş. (2010). Okul öncesi dönem çocuklarının bilimsel süreç becerilerini kullanma yeterliliklerini geliştirmeye yönelik pilot bir çalsşma. Necatibey Eğitim Fakültesi Elektronik Fen ve Matematik. Ë̈itimi Dergisi (EFMED), 4(2), 1-24.

Bal, E. (2018). FeTeMM (Fen, Teknoloji, Mühendislik, Matematik) etkinliklerinin 48- 72 ayllk okul öncesi çocuklarmm bilimsel süreç ve problem çözme becerileri üzerindeki etkisinin incelenmesi. Yayımlanmamış Yüksek lisans tezi. Marmara Üniversitesi, İstanbul.

Brenneman, K. (2011). Assessment for Preschool Science Learning and Learning Environments. Early Childhood Research \& Practice, 13(1), n1.

Büyüköztürk, Ş. (2002). Sosyal bilimler için veri ve analiz̧i el kitabı: istatistik, araştırma deseni, SPSS uygulamalar ve yorum. Pegem A Yayıncilik.

Büyüköztürk, Ş., Çakmak, E. K., Akgün, K. Ş., Karadeniz, Ş., \& Demirel, F. (2012). Bilimsel araștrrma yöntemleri. (12. Basım). Ankara: Pegem.

Büyüktaşkapu, S. (2010). 6 yaş çocuklarnın bilimsel süres becerilerini gelistirmeye yönelik yapulandırmacı yaklaşıma dayal bir bilim ögretimi programı. Doktora Tezi. Selçuk Üniversitesi Sosyal Bilimler Enstitüsü, Konya. 
Büyüktaşkapu, S., Çeliköz, N., \& Akman, B. (2012). Yapılandırmacı Bilim Eğitimi Programı'nın 6 Yaş Çocuklarının Bilimsel Süreç Becerilerine Etkisi. Eğitim ve Bilim, 37 (165), 276-292.

Bybee, R. W. (2010). What is STEM education? http://science.sciencemag.org/ adresinden erişilmiştir. DOI:10.1126/science.1194998.

Chittleborough, G. D., Treagust, D. F., Mamiala, T. L., \& Mocerino, M. (2005). Students' perceptions of the role of models in the process of science and in the process of learning. Research in Science \&o Technological Education, 23(2), 195-212.

Civelek, P., \& Akamca, G. Ö. (2018). Açık Alan Etkinliklerinin Okul Öncesi Dönemdeki Çocukların Bilimsel Süreç Becerilerine Etkisi. Kastamonu Eğitim Dergisi, 26(6), 2011-2020.

Creswell, J. W. (2013). Araştırma deseni: Nitel, nicel ve karma yöntem yaklaşımları. (Çev. edt: SB DEMIR) Ankara: Ë̈ten Kitap.

Çilengir-Gültekin, S. (2019). Okul öncesinde eğitimde drama temelli erken STEM programmm bilimsel süreç ve yaratıc düsünme becerilerine etkisi (Yüksek lisans tezi). Aydın Adnan Menderes Üniversitesi, Aydın.

Çorlu, M. A., \& Aydin, E. (2016). Evaluation of learning gains through integrated STEM projects. International Journal of Education in Mathematics, Science and Technology, 4(1), 20-29.

Çorlu, M. S., Capraro, R. M., \& Capraro, M. M. (2014). Introducing STEM education: Implications for educating our teachers in the age of innovation. Education and Science, 39(171), 74-85.

Deniz-Özgök, A. (2019). 60-75 ayllk cocuklarn STEM etkinliklerinde problem çözme ve bilişsel düsünme becerilerinin incelenmesi. Yayımlanmamıș Yüksek lisans tezi. Bahçeșehir Üniversitesi, İstanbul.

Eshach, H., \& Fried, M. N. (2005). Should science be taught in early childhood? Journal of Science Education and Technology, 14(3), 315-336.

French, L. (2004). Science as the center of a coherent, integrated early childhood curriculum. Early Childhood Research Quarterly, 19(1), 138.

Güldemir, S. (2019). Okul öncesi eğitiminde STEM etkinliklerinin yaratıclĭga etkisi. Yayımlanmamış Yüksek lisans tezi. Recep Tayyip Erdoğan Üniversitesi, Rize.

Güler, T., \& Akman, B. (2006). 6 yaş çocuklarının bilim ve bilim insanı hakkındaki görüşleri. Hacettepe Üniversitesi Ë̈itim Fakültesi Dergisi,31,55-56.

Günşen, G., Fazlığlu, Y., \& Bayır, E. (2017). STEM Yaklaşımına Dayalı Okul Öncesi Öğretim Uygulama Örneği ve Uygulamanın 5 Yaş Çocukları Üzerine Etkileri. 2017 Bildiri Özetleri Kitabr, s(599-600).

Haden, C. A., Jant, E. A., Hoffman, P. C., Marcus, M., Geddes, J. R., \& Gaskins, S. (2014). Supporting family conversations and children's STEM learning in a children's museum. Early Childhood Research Quarterly, 29(3), 333-344.

Harlen, W., \& Jelly, S. (1989). Developing science in the primary classroom. London.

Haslam, F., \& Gunstone, R. (1996). Observation in science classes: Students' beliefs about its nature and purpose. Annual Meeting of the National Association for Research in Science Teaching. St Louis, MO.

Holt, B.G. (1991). Science with young children. Washington. National Association For The Education Of Young Children.

Honey, M., Pearson G., \& Schweingruber, H. (2014). STEM integration in K-12 education: status, prospects and an agenda for research. Washington: The National Academic Press. 
Ing, M. (2014). Can parents influence children's mathematics achievement and persistence in STEM careers? Journal of Career Development, 41(2) 87-103.

Jamil, F. M., Linder, S. M., \& Stegelin, D. A. (2018). Early childhood teacher beliefs about STEAM education after a professional development conference. Early Childhood Education Journal, 46(4), 409-417.

Johnson, B., \& Christensen, L. (2014). Ë̆itim araştırmalar: nicel, nitel ve karma yaklaşımlar. (Çev. Ed. SB DEMİR) Ankara: Eğiten Kitap.

Kandemir, E.M. (2011). Öğretmenlerin üst düzey bilimsel süreç becerilerini anlama düzeylerinin belirlenmesi. Yayınlanmamış Yüksek Lisans Tezi, Ege Üniversitesi Sosyal Bilimler Enstitüsü, İzmir.

Karataş, F. N. (2018). İlk Yillar eğitim programmm (Primary Years Programme) okul öncesine devam eden cocuklardaki Bilimsel Süreç Becerilerine (BSB) etkisi. Yayımlanmamış Yüksek Lisans Tezi, Yıldız Teknik Üniversitesi Sosyal Bilimler Enstitüsü, İstanbul.

Kavak, Ş. (2020). STEM Eğitimine Dayah Etkinliklerin Okul Öncesi Cocuklarn Temel Bilimsel Süreç Becerilerine Etkisi. Yayımlanmamış Doktora Tezi. Çukurova Üniversitesi, Adana.

Kazakoff, E. R., Sullivan, A., \& Bers, M. U. (2013). The effect of a classroom-based intensive robotics and programming workshop on sequencing ability in early childhood. Early Childhood Education Journal, 41(4), 245-255.

Kefi, S., Çeliköz, N., \& Erişen, Y. (2013). Okul öncesi eğitim öğretmenlerinin temel bilimsel süreç becerilerini kullanım düzeyleri. Eğitim ve Öğretim Araștırmalar Dergisi, 2 (2), 300-319.

Kıldan, O., \& Pektaş, M. (2009). Erken çocukluk döneminde fen ve doğa ile ilgili konuların öğretilmesinde okul öncesi öğretmenlerinin görüşlerinin belirlenmesi. Abi Evran Üniversitesi Kurșehir Ë̈̆tim Fakültesi Dergisi, 10(1), 113-127.

Koray, Ö., Köksal, M.S., Özdemir, M., \& Presley, A.İ. (2007). Yaratıcı ve eleştirel düşünme temelli fen laboratuvarı uygulamalarının akademik bașarı ve bilimsel süreç becerileri üzerine etkisi. İlkögretim Online, 6(3), 377-389.

Köklü, N. Büyüköztürk, Ş. ve Bökeoğlu, Ö. Ç. (2006). Sosyal bilimler için istatistik. Ankara: PegemA yayincilik.

Kumtepe, E. G., Kaya, S., \& Kumtepe, A. T. (2009). The effects of kindergarten experiences on children's elementary science achievement. İlkögretim Online, 8(3).

Lamb, R., Akmal, T., \& Petrie, K. (2015). Development of a cognition-priming model describing learning in a STEM classroom. Journal of Research in Science Teaching, 52(3), 410-437.

Lippard, C. N., Lamm, M. H., Tank, K. M., \& Choi, J. Y. (2019). Pre-engineering Thinking and the Engineering Habits of Mind in Preschool Classroom. Early Childhood Education Journal, 47(2), 187-198.

MEB (2013). (36-72 Aylık) Okul Öncesi Eğitim Programı. Millî Eğitim Bakanlı̆̆ Talim ve Terbiye Kurulu Başkanlığı. Ankara.

Miles, M. B., \& Huberman, A. M. (1994). Qualitative data analysis: An expanded sourcebook. SAGE.

National Research Council (1996). National science education standards. Washington, D.C.: National Academy Press.

Öcal, S. (2018). Okul Öncesi Eğitime Devam Eden 60-66 Ay Cocuklarna Yönelik Geliştirilen STEM Programmm Cocuklarn Bilimsel Süreç Becerilerine Etkisinin Incelenmesi. Yayımlanmamış Yüksek Lisans Tezi. Yıldız Teknik Üniversitesi, İstanbul. 
Özkan, B. (2015). 60-72 Ayllk Çocuklar İ̧̧in Bilimsel Sürȩ̧ Becerileri Ölçeğinin Geliştirilmesi ve Beyin Temelli Ögrenmeye Dayanan Fen Programmm Bilimsel Sürec Becerilerine Etkisi. Yüksek Lisans Tezi. Marmara Üniversitesi Sosyal Bilimler Enstitüsü, İstanbul.

P21 (2017) The Partnership for 21st Century Learning. 19.04.2020 tarihinde www.p21.org adresinden alınmıştır.

Park, D. Y., Park, M. H., \& Bates, A. B. (2018). Exploring young children's understanding about the concept of volume through engineering design in a STEM activity: A case study. International Journal of Science and Mathematics Education, 16(2), 275-294.

Ramey-Gassert, L. (1997). Learning science beyond the classroom. The Elementary School Journal, 97(4), 433-450.

Sağırekmekçi, H. (2016). Tahmin-göə̆lem-açıklama stratejisine dayalı fen ve doğa etkinliklerinin, bilimsel süreş becerilerine ve bilisssel alan yeteneklerine etkisi. Yayımlanmamıs Yüksek Lisans Tezi, Mustafa Kemal Üniversitesi Fen Bilimleri Enstitüsü, Hatay.

Strong, M. G. (2013). Developing elementary math and science process skills through engineering design instruction. Master Thesis, Hofstra University.

Şahin, F., Güven, İ., \& Yurdatapan, M. (2011). Proje tabanlı eğitim uygulamalarının okul öncesi çocuklarında bilimsel süreç becerilerinin gelişimine etkisi. Marmara Üniversitesi Atatürk Ë̈itim Fakültesi Dergisi, 33, 157-176.

Şahin, F., Yıldırım, M., Sürmeli, H., \& Güven, İ. (2018). Okul öncesi öğrencilerinin bilimsel süreci becerilerinin değerlendirilmesi için bir test geliștirme çalışması. Bilim, Eğitim, Sanat ve Teknoloji Dergisi (BEST Dergi), 2(2), 124-138.

Tan, M., \& Temiz, B. K. (2003). Fen öğretiminde bilimsel süreç becerilerinin yeri ve önemi. Pamukkale Üniversitesi Eğitim Fakültesi Dergisi. 13 (1), 89-101.

Tekerci, H., \& Kandır, A. (2017). Effects of the Sense-Based Science Education Program on Scientific Process Skills of Children Aged 60-66 Months. Eurasian Journal of Educational Research, 17 (68), 239-254.

Tippett, C. D., \& Milford, T. M. (2017). Findings from a pre-kindergarten classroom: Making the case for STEM in early childhood education. International Journal of Science and Mathematics Education, 15(1), 67-86.

Toprakkaya, İ. M. (2016). 55-72 Ayllk Cocuklara Dıs Alanda Uygulanan Sorgulama Tabanl Bilim Etkinlikelerinin Bilimsel Süreç Becerilerine Etkeisinin Incelenmesi Yayımlanmamış Yüksek Lisans tezi. Okan Üniversitesi Sosyal Bilimler Enstitüsü, İstanbul.

Trundle, K. C., \& Saçkes, M. (Eds.). (2015). Research in early childhood science education. Springer.

Tuncer, M. (2020). Nicel Araştırma Desenleri. Oral, B. ve Çoban, A. (Ed.) Kuramdan Uygulamaya Ĕ̈itimde Bilimsel Araștırma Yöntemleri içinde (s. 205-228). Ankara: Pegem Akademi.

Uğraş, M. (2017). Okul öncesi öğretmenlerinin STEM uygulamalarına yönelik görüşleri. Eğgitimde Yeni Yaklaşımlar Dergisi 1(1), 39-54.

Uyanık-Balat, G., \& Günşen, G. (2017). Okul öncesi dönemde STEM yaklaşımı. The Journal of Academic Social Science, 5(47), 337-348.

Üret, A. (2019). STEM eğitiminin 5 yaş çocuklarnm yaratıcllklar üzerindeki etkisi. Yayımlanmamış Yüksek lisans tezi. Yıldız Teknik Üniversitesi, İstanbul.

Vurucu, C. (2019). Erken çocukluk döneminde bilim ve mühendislik uygulamalarmın ögrencilerin bilimsel süreç becerilerine, karar verme ve problem çözme becerilerine etkisi. Yayımlanmamış Yüksek lisans tezi. Marmara Üniversitesi, İstanbul. 
Yağc1, M. (2016). Okul öncesi dönem çocuklarmm bilimsel süreç becerilerinin gelismesinde doğa ve çevre uygulamalarmm etkisinin incelenmesi. Yayımlanmamış yüksek lisans tezi. Abant İzzet Baysal Üniversitesi Eğitim Bilimleri Enstitüsü, Bolu.

Yamak, H., Bulut, N. \& Dündar, S. (2014). 5. sınıf öğrencilerinin bilimsel süreç becerileri ile fene karşı tutumlarına FeTeMM etkinliklerinin etkisi. Gaæ̌i Üniversitesi Eğitim Fakültesi Dergisi, 34(2), 249-265.

Yıldırım, B. \& Altun, Y. (2015). STEM eğitim ve mühendislik uygulamalarının fen bilgisi laboratuvar dersindeki etkilerinin incelenmesi. El-Cezeri Journal of Science and Engineering, 2(2). 